\title{
Economic texts as a reflection of the social reality of the transition period in Latvia and Russia*
}

\author{
I. Mietule ${ }^{1}$, V. Komarova ${ }^{2}$, I. Ostrovska ${ }^{2}$, S. Ignatyevs ${ }^{3}$, B. Heimanis ${ }^{3}$ \\ ${ }^{1}$ Rezekne Academy of Technologies \\ Atbrivosanas Al., 115, LV-4601, Rezekne, Latvia
}

${ }^{2}$ Daugavpils University

Vienibas St., 13, LV-5401, Daugavpils, Latvia

${ }^{3}$ Baltic International Academy

Lomonosova St., 4, Riga, LV-1019, Latvia

(e-mails: iveta.mietule@rta.lv; vera.komarova@du.lv;

inta.ostrovska@du.lv; igs@bk.ru; boriss.heimanis@gmail.com)

\begin{abstract}
The goal of the study is to compare the reflection of Latvia's and Russia's transition to the market economy in economic texts. The object of the research is Latvian and Russian textbooks on economics $(\mathrm{N}=61)$ of 'three generations' (1990s, 2000s and 2010s) in the Daugavpils University library. The first such textbooks were published in 1993, and the last ones - in 2015. Although the starting point of the analysis is the translation of Samuelson's textbook (1964), which is beyond the time scope of the research, this book is necessary for a deeper analysis of the textbooks on economics. The research was conducted with the descriptive analysis and case study method applied in the framework of the linguistic discourse analysis based on Weber's methodology of cultural determinism. The results of the research showed that in the 1990s, the economic discourse of the USA was actively borrowed in Latvia and Russia; however, the business culture of the USA differs significantly from the business culture of our countries. The linguistic discourse analysis allowed to reveal the conceptual challenges of the contemporary economic science in Latvia and Russia: despite as if the existence of some general economic theory, in reality even basic economic processes are often explained in different conceptual systems depending on the beliefs of the economic texts' authors. Considering the social-economic transformations in the past thirty years and earlier periods, the authors emphasize the special importance of critical thinking in the creation, translation and perception of economic texts. This is especially important since there are no reasons to believe that in the 1990s, the cultural component of the economic discourse of Latvia and Russia changed significantly to the market-oriented. Today readers of economic texts have difficulties in their critical assessment, especially of those texts whose authors use emotional terminology.
\end{abstract}

Key words: text; social-cultural context; economic discourse; economic texts; linguistic discourse analysis; cultural determinism

The social-economic structure and economic science in Latvia and Russia (both were parts of the same country - the Russian Empire until 1918 and the USSR (1940-1990)) have moved from the discourse of the capitalist economy of

* (C) I. Mietule, V. Komarova, I. Ostrovska, S. Ignatyevs, B. Heimanis, 2022

The article was submitted on 09.10.2021. The article was accepted on 17.12.2021. 
the late $19^{\text {th }}$ - early $20^{\text {th }}$ centuries to the discourse of the planned socialist economy of the mid- $20^{\text {th }}$ century, then to the discourse of the transitional economy in the late $20^{\text {th }}$ century and finally to the discourse of the contemporary market economy in the early $21^{\text {st }}$ century. Accordingly, economic texts, including textbooks on economics for the professional training, and economic terminology have changed. The creation, translation and perception of economic texts are connected with the social-economic processes in Latvia and Russia. Despite the fact that both Latvia and Russia have followed the path of the market economy for thirty years, the challenges of translation and use of the market terminology in the economic discourse is still relevant. The State Language Center (Valsts valodas centrs) of Latvia outlines the following main issues in translating terminology: the use of synonymous terms, arbitrary expansion, narrowing or clarification of concepts, influence of other languages on national terminology [39], in particular, "enormous influence that English as the main lexical donor to other European languages have in business and economics fields" [48].

The aim of this study is a comparative analysis of the social context of the creation, translation and perception of textbooks on economics of the 1990s, 2000s and 2010s. The object of the research is Latvian and Russian textbooks on economics $(\mathrm{N}=61)$ in the Daugavpils University library, with the exception of a few translated books by Krugman and Piketty, which, although they are not textbooks, are also included in the research because of their popularity and applicability for teaching economists. The Daugavpils University library receives textbooks on economics not only in Latvian and foreign languages, but also in Russian - both through centralized purchases and within scientific or development projects. According to the data provided by the director of the Daugavpils University library, 22\% of the books in the section 'Economics' are in Russian; the Daugavpils University publishes scientific books in Russian.

The research was conducted with the following methods in the framework of the linguistic discourse analysis based on Weber's methodology of cultural determinism: descriptive analysis $[25 ; 60]$ - to study the social context of the creation, translation and perception of Latvian and Russian textbooks on economics of the 1990s, 2000s and 2010s; case study [7; 53] — to analyze the social context of the Russian translation and perception of the classical market textbook on economics by Samuelson.

The linguistic field of the economic discourse of several periods through which Latvia and Russia have passed consists of many specific economic terms. For example, one can mention such typical representers of the planned socialist economy as 'five-year plan' (piecgade, пятилетка) [9; 33; 41], 'cadrs' (kadri,

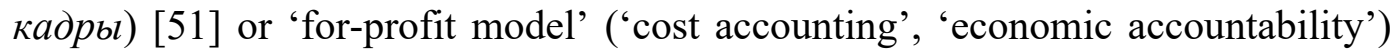
(saimnieciskais aprēk,ins, хозрасчет, хозяйственный расчет) [1;29; 51], and of the market economy - 'invisible hand' (neredzamā roka, невидимая рука) of market [8; 54], first used by Smith in his classical works back in the $18^{\text {th }}$ century and included in textbooks on economics. 
Over the last thirty years, in the post-Soviet space, economic texts have fulfilled an ideational metafunction [21], which helps to show Latvian and Russian readers the experience of the developed market economy (in general, the USA) as unknown in the 'Soviet economy' [14]. Thus, in Latvia and Russia during the transition from the planned economy to a market economy, economic texts are a vivid example that "between the level of readers' knowledge, which the author of the source text expects, and the preliminary awareness of the target groups, which the translator expects, there may be a noticeable difference" [61]. The methodological basis of this study is not a critical but rather an explanatory assessment of economic texts - a normative-descriptive approach and the linguistic discourse analysis $[3 ; 6 ; 16 ; 25 ; 47 ; 61 ; 62]$.

We believe that to understand the specifics of the linguistic discourse analysis, it is necessary to define 'discourse' in social sciences and in particular in linguistics. "Discourse is the unity of the process of linguistic activity and its result, that is, the text. Discourse includes text as an integral part. Text is a static object that arises in the course of linguistic activity... The discourse, in addition to the text itself, also includes the dynamic processes of its creation and understanding" [25]. Figure 1 presents our understanding of the essence of discourse, which also helps to separate 'text' and 'discourse'. Thus, we focus on the creation, translation and perception of Latvian and Russian textbooks on economics of three generations (1990s, 2000s and 2010s) and on social processes that determine such a creation, translation and perception, i.e., the linguistic features of the economic discourse [3] in the 1990s, 2000s and 2010s (Table 1).

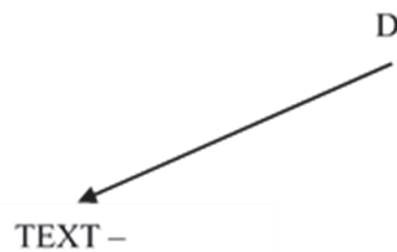

a static object, a result of the social (in linguistics language) activity

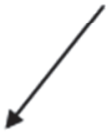

Text (written or oral) in linguistics or 'social text' (social status, property, political power, etc.) in social sciences

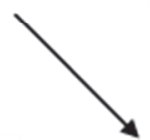

Corpus of texts a collection of texts that create common meanings

\section{DISCOURSE}

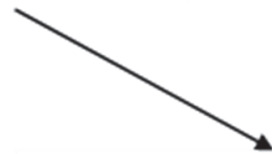

CONTEXT -

social processes that determine the creation, translation (adaptation) and perception (analvsis) of texts

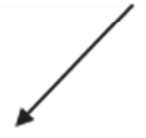

Background processes of social reality that determine creation (synthesis) and translation (adaptation) of texts

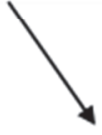

Background processes of social reality that determine perception (analysis) of texts

Fig. 1. The essence of discourse in social sciences [based on: 25; 62]

"Usually discourse and text are opposed to each other using a number of criteria: functionality/structurality, process/product, dynamics/statics and actuality/virtuality" 
[6]. We believe that, according to Van Dijk who identified two aspects of the discourse analysis - textual and contextual [62], we can define discourse in linguistics as a text in a context. Such a definition can be applied in any science, art and other human activity, while the 'text' should be defined broader - as a product of any human activity. For instance, in music, discourse is a piece of music (musical text) in the context of the social reality it was created in (and/or perceived), in painting - a piece of art (visual text) in the same type of context, in sociology a social status (social text) (1), in economics - a property (economic text), in the industry - a car (technical text), etc.

Table 1

Structure of the research object: textbooks on economics of the 1990s, 2000s and 2010s

\begin{tabular}{|l|c|c|c|c|}
\hline Indicators & 1990s & 2000s & 2010s & Total \\
\hline Number of textbooks & 27 & 22 & 12 & 61 \\
\hline - in Latvian & 14 & 14 & 7 & 35 \\
- in Russian & 13 & 8 & 5 & 26 \\
\hline - translated & 11 & 7 & 7 & 25 \\
- original & 16 & 15 & 5 & 36 \\
\hline - general & 18 & 13 & 6 & 37 \\
- specialized & 9 & 9 & 6 & 24 \\
\hline
\end{tabular}

Indeed, a research in any science or art will be much deeper and 'qualitative' if one investigates not only the text but also the context of its creation and perception. Thus, the social status of an entrepreneur can be for the sociologist both a social text and a discourse, depending on whether this status is considered in the social-historical context of its acquisition, transformation and perception (e.g., from the deviant status of the kulak in the Soviet period to the status of a driving force of the economic development during the transition to the market economy) or only in the perspective of its structural characteristics in the contemporary society (e.g., the so-called 'sociological portrait' of the entrepreneur - income, education, etc.). Text and context within the discourse influence each other, i.e., the text is created and perceived within the context and at the same time affects the context; if the context of the creation of the text and the context of its perception represent different historical periods, then the text is a kind of a bridge between these periods, and the past influences the present.

Within the contextual approach of the linguistic discourse analysis [16], it is generally accepted that the text as a product of language activity is woven into 'webs of significance' - networks created by authors and addressees, society and culture [11], in which it became possible and necessary for specific activities, in particular, such are textbooks on economics. History is represented in the text and its translations, since any statement (text) as a product of social activities is always a part of social interactions and structures in a specific political and culturalhistorical situation [47]. Therefore, webs of significance can be defined as systems of meanings that help people communicate with each other and the world [11].

The contextual level of the linguistic discourse analysis is based on the idea that the text represents, reproduces, points to and names something — this is what 
is commonly called the referent or denotatum and reveals the social relations of communication and various cultural codes of the speech [47]. For instance, the discourse analysis of the statements of scientists mainly in natural sciences [12] revealed the relatively poor investigated aspects of scientific activities and socialcultural, institutional, communicative and personal aspects of cognition. Van Dijk developed a situational model of discourse analysis for communicative interactions not as rigidly algorithmic but rather flexible strategic procedures [61]. Based on the findings in the field of grammar, pragmatics of discourse and cognitive model of communication, Van Dijk described the specific functions of language in the media considering such social factors as opinions and attitudes of the speaker and listener, their social status, ethnicity, and so on [62].

Weber's cultural determinism is a useful methodological tool to implement the contextual approach of the linguistic discourse analysis in the study of culture as a system of meanings in the creation, translation and perception of textbooks on economics. According to Weber, the basis of the social development is religion, i.e., the sphere of public consciousness [64]. For Weber, religion is the result of the doubling of the world; thus, he is close to Marxists in defining religion as a fantastic reflection of those external forces that dominate in everyday life [59]. But the explanations differ: "If for Marxists religion as a reflection of social and natural reality does not play a primary role in the social process, then for Weber this role is decisive, since religion is a system of values and meaning that motivates and justify the behavior of people" [59].

To implement a comparative approach, we divided the time since the beginning of the transition of Latvia and Russia to the market economy into three periods - the 1990s, 2000s and 2010s, although the development of the economic discourse rather was gradual, i.e., for instance, features of the 2000s had developed already in the 1990s and, probably, even earlier. Nevertheless, in each of these conditional periods, in the development of the economic discourse in the Latvian and Russian spaces, we tried to find certain dominant characteristics of the social context of the creation, translation and perception of economic texts.

The experimental period. In the early 1990s, undet the post-Soviet economy transition to the 'market rails' (рыночные рельсы) [13] (2), many economic terms were borrowed from English (franchising, factoring, clearing, leasing, etc.) in Latvian and Russian economic texts $[10 ; 50]$ within the so-called 'terminological influx' (терминологический потоп) [26]. The realities which they defined were either absent at that time (3) or were slowly developing [52]. During this period, many Latvian and Russian textbooks on economics were published as experimental editions $[20 ; 40]$ in the framework of international projects [e.g., 27]. In general, they were to "update the university education in economics and move it closer to the world standards" [27].

The 1990s were a controversial and interesting stage in the development of the economic discourse in Latvia and Russia. In 1991, one of the leading Soviet economists Shatalin described the economic situation in the country at that time as "an economic crisis and a complete deficit at the wholesale and consumer markets" 
[13]. Therefore, economic texts of the period declared that: (1) An urgent need for the transition to the market economy determined the development of various market conceptions. The very idea of the market was discussed not only by specialists, parliamentarians and scientists but penetrated into the public consciousness as directly affecting the vital interests of all people [13]; (2) There are cases in history when literally one word becomes a symbol of the era as absorbing the most complex concepts of the whole world. For instance, the Russian word perestroika lost its original, narrow practical meaning and became a universal symbol of the desire to reorganize social relations [34].

The 1990s are also called the period of the market romanticism due to the idea that all aspects of the social-economic life can be built on market principles personal interests, private property, competition, profit, etc. However, sociological surveys in the city of Daugavpils, conducted in the 1990s by the Laboratory of Sociological Research of the Daugavpils Pedagogical University [31], showed that estimates of the transition to the market economy differed (Fig. 2).

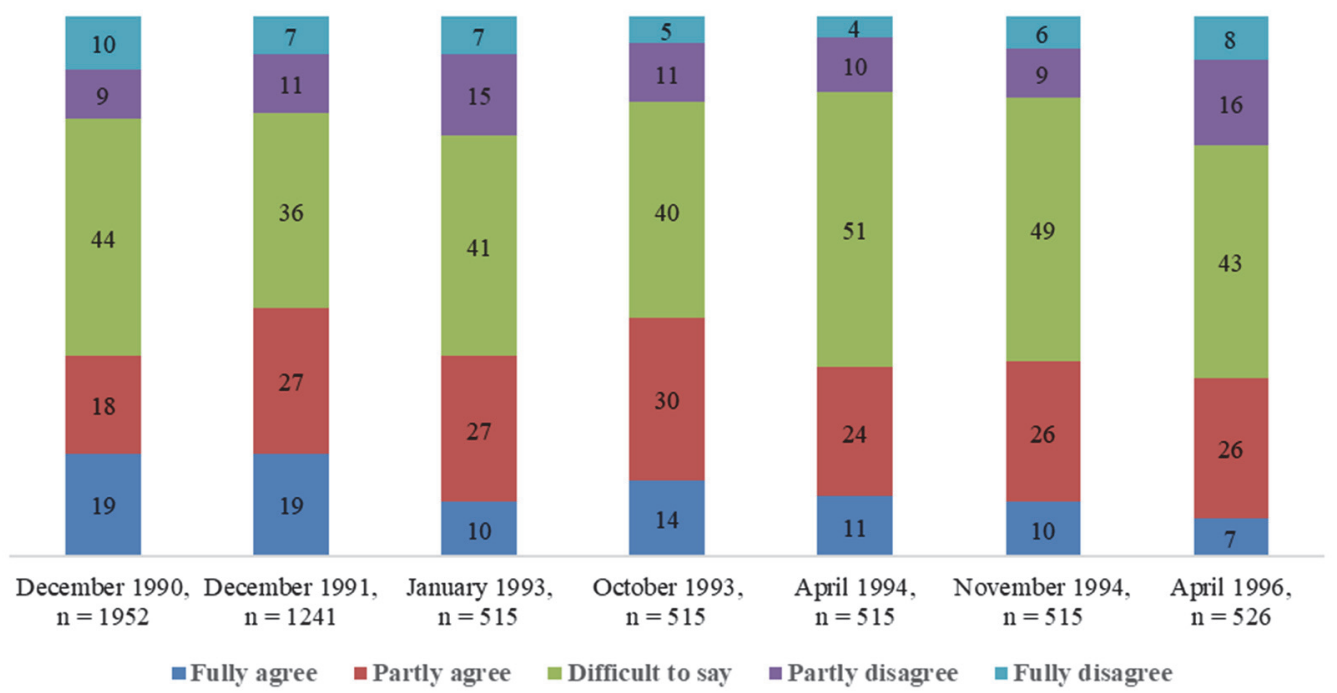

Fig. 2. "Do you agree that the transition to the market economy will help our society overcome the crisis and ensure a normal life?" (\%, 1990-1996) [31]

The analysis of the content of economic texts published in the 1990s also proves that there was no unconditional acceptance of the market in the economic discourse, e.g., the Latvian economist Bikse considered this period as "the transition from the command economy to the mixed economy" [4]. The authors of the manual "for business leaders, officials of planning agencies, teachers and students, researchers" Vid and Ivanov named their book New Philosophy of Planning (1990), in which they interpret in a very peculiar way the nature of the relationships between plans and market: "The most decisive expansion of the sphere of the commoditymoney relations and the boundaries of economic independence of the main unit of production - the enterprise - not only does not weaken, but, on the contrary, strengthens the role of central planning. It is this dialectical understanding of 
changes in the forms and methods of the planned economic management that determines new approaches to planning, which are fully expected to be implemented in the thirteenth 5-year plan" [63].

The term 'legal economy' (правовая экономика), first used by Gorbachev at the First Congress of the People's Deputies of the USSR [34], was defined in the economic texts of that time as follows: "The establishment of clear legal norms determining the economic sovereignty of the producer and the consumer is the foundation for democratization of economic life, ensuring the right to choose economic partners, the areas of application of earned funds, and the range of products and services consumed. All this can be achieved only through the development of the socialist market. Humanity has not developed another mechanism for democratization of the economic life. We must master this experience in full and use it to increase the effectiveness of the socialist economy" [34].

The textbook on economics with a fashionable market title Economics: Theory and Practice (1993) provided a "detailed and systematic presentation of the basics of business" [24]. And there were no longer claims to contribute to improving the effectiveness of the socialist economy. The textbook was intended for entrepreneurs and businessmen living in the country that had chosen the market path of the economic development.

Thus, the social context of the creation, translation and perception of textbooks on economics at the very beginning of the transition of Latvia and Russia to the market economy was very contradictory. This was reflected in textbooks on economics - in particular, in linguistic representations of both planned and market economies, and in the intricate 'Soviet-market' linguistic constructions, for instance, 'propaganders for the sale of goods at the enterprise' (пропагандисты по сбыту товаров на предприятии) [24].

In the universities of Latvia, Russian translations of textbooks on economics by McConnell and Brew or Samuelson were dominant during this period, and there were practically no other market textbooks in Russian, and even in Latvian. By the mid-1990s, they were supplemented by the Latvian textbooks on economics, which began to be published by local economists or translated into Latvian in the framework of international projects.

Relatively mature period (2000s). The next period representing the social context of the creation, translation and perception of Latvian and Russian textbooks on economics started with the world financial crisis of 1997-1998, which especially affected the countries of Southeast Asia and Russia [2] (the so-called 'default of 1998'). This crisis had some sobering cold shower effect for the economic discourse of the Latvian and Russian spaces: "The reformers argued that price liberalization would create a market that would begin to regulate the entire economy and its development. But inflation has become like a fabulous genie that was released from the bottle, and it caused a lot of troubles" [5]. As Pokornyak, the CEO of one of the Russian companies, said: "the default killed a certain market romanticism in me. Today I evaluate many things in a different way" [37]. 
In one of the forewords to textbooks on economics of the 2000s, it is argued that "emerging economies such as China, India and Russia - the three giants that have recently focused on central planning - need a solid understanding of the institutions of the market economy. Only in this case they can reach the standard of living of the developed countries" [46]. During this period, new editions of American classic textbooks on economics [30; 46] were translated into Russian and provided "a clear, accurate and as interesting as possible presentation of basics of the modern economic theory", including both "imperishable truths of economics" and "political problems of the new century" [46]. Thus, the dominant framework of the 2000s was the relative market enlightenment of the economic discourse. This was in contrast to the experimental period of the creation, translation and perception of market textbooks on economics of the 1990s, when the meaning of economic terms and texts depended on the completely Soviet consciousness of their creators and translators.

During this period, the universities of Latvia which had sufficiently adapted to the new social-economic reality, had a fairly large number of Latvian textbooks on economics. These were textbooks both by Latvian economists and translations into Latvian from English, German and even Norwegian. Nevertheless, the classic textbooks by McConnell, Brew and Samuelson (co-authored with Nordhaus) continued to be the most popular and basic textbooks on economics for the Russianspeaking students. Although, for example, the Daugavpils University library had textbooks on economics also by other Western authors - Mankiw, Brigham, Krugman and Obstfeld - in Russian together with the textbooks by Russian authors - Borisov, Fomichev, Bakanov and Sheremet, the textbooks that won their positions in the first half of the 1990s were still the most popular.

Critical period (2010s). This period started with the global financial crisis of 2008 which had enormous negative consequences for the whole world including Latvia. This crisis had an even stronger cold shower effect for the economic discourse of the Latvian and Russian spaces and lead to the textbooks on economics with such typical phrases as 'in search of another economy', 'failure of 'inflated' capitalism', 'alternative development paths', 'sick blood' of the economy' [36]. Economists of the post-Soviet social-economic space started talking about the special importance of the cultural context: "The fail shows that cultural roots are weak or unsuitable for the prevailing economic relations" [36].

The period of the 2010s is characterized by a sharp decline in the number of textbooks on economics - their place sometimes was taken by economic texts analyzing the economy and discussing various options for overcoming the crisis (which has become an almost constant characteristics of every period under study), for instance, the Latvian translation of the book by the famous American economist Krugman The Return of the Depressive Economy and the 2008 Crisis (2010), Latvian and Russian translations of the fundamental work of the French economist Piketty Le Capital au XXI Siecle (2015). Textbooks on economics become more analytical and less elementary, one can even find justified calls for the return of the use of the old economic terminology: "I prefer the concept 'political economy', 
which may sound a little old-fashioned, but has the virtue of reflecting the only acceptable feature of economics within the social sciences, which is its political, normative and moral dimension" [35].

Moreover, over the past few years, electronic copies of the famous Stalinist textbook on political economy [33] have appeared in the Runet, in which the quintessence of the Soviet economic thought of the 1930s, 1940s and early 1950s is presented. The Russian Information portal of supporters of the referendum on the responsibility of the authorities to the people informs: "A lot of time has passed, and now the generation that did not live under Stalin and barely remember the USSR began to increasingly turn to the experience of those who built the first socialist society in history. ... Read this book. Learn from this tutorial" [22].

Thus, the recent period of the creation, translation and perception of textbooks on economics can be characterized as absolutely pluralistic: today in the Latvian and Russian economic discourses, textbooks on economics represent both classical economic science and the pre-revolutionary, Stalinist, socialist, capitalist, etc., although the curricula of the universities in both Latvia and Russia are now dominated by classical market textbooks on economics. Furthermore, future economists are less likely to go to the library (also due to the covid-19 pandemic) and more often download textbooks on economics from the Internet, choosing from a variety of options in Latvian, Russian or English.

In Latvia, there is an interesting example of the translation of two editions of the textbook on economics not from English (which is traditional for Latvian and Russian economists), but from Norwegian. In this textbook, there are many types of production costs which are not mentioned in other textbooks on economics (e.g., progressively variable costs, proportionally variable, regressively variable, hopping fixed and differential) [17]. The main author, the Norwegian economist Hofs, taught for several years at the Faculty of Engineering Economics of the Riga Technical University and enriched the Latvian economic discourse with a piece of the Norwegian economic discourse in the form of two economic texts representing the specifics of the Norwegian economic culture and business practices. We believe that such an experience of translating economic texts from different languages (e.g., Chinese, Swedish, Korean, and others) will enrich Latvian and Russian economic discourses with a completely new economic culture and business practices.

Now we will illustrate the cultural context of the USA economic discourse in comparison with the cultural context of the economic discourse of the 'recipient' countries - Latvia and Russia. Since culture is the most inert element of the society [19], the cultural component measured for many countries within the famous project (related mainly to the business culture) by the Dutch scientist Hofstede, can be considered a constant of the social context of the creation, translation and perception of textbooks on economics in the 30-year period under study. The Figure 3 shows a graphical comparison of the cultures of three countries - Latvia, Russia and the USA - according to Hofstede's six cultural dimensions [19]. Thus, the culture of the USA significantly differs from the culture of Latvia and Russia in all six dimensions. According to Hofstede, "national culture cannot be changed, but 
you should understand and respect it" [19]. Cultures of Latvia and Russia are also quite different, first of all, in terms of power distance (much higher in Russia), individualism (much higher in Latvia) and uncertainty avoidance (much higher in Russia).

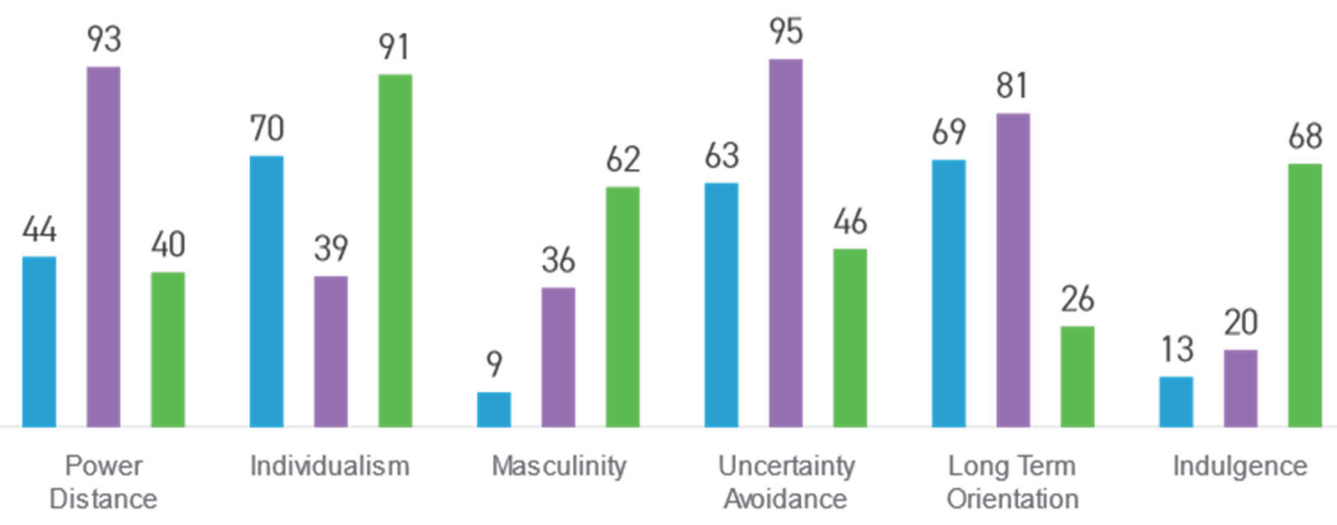

Fig. 3. Comparison of the culture of Latvia, Russia and the USA according to G. Hofstede's six cultural dimensions [based on 20]

The most noteworthy thing in the cultural aspect of the creation, translation and perception of textbooks on economics is that both Latvia and Russia (unlike the USA) have a fairly high score for cultural flexibility ( $5^{\text {th }}$ cultural dimension), i.e., the culture of the Latvian and Russian spaces "is of a pragmatic nature. In pragmatic societies, people believe that truth is very much dependent on situation, context and time. They demonstrate the ability to easily adapt traditions to changing conditions" [20]. Nevertheless, as Hofstede and his followers [18] stress, such an acclimation of the webs of significance [11] of an 'alien' culture is largely formal, superficial and ostentatious. For example, in the following quote from the translation of the textbook by two American economists - Heilbroner and Thurow [15], the cultural context of the translator as representing a different social context from the Soviet life is manifested: "в условиях конкуренции фирма... чтобы выжсить, скорее будет скупердяйничать" - "in a competitive environment, the company... in order to survive, will rather be stingy' (the word 'скупердяйничать' is not the only translation option for the word 'stingy', but the translator chose this particular word with a clearly negative connotation) - "и искать одну только выггоду" — and "look for only profit" (this also reveals a latent rejection by the Soviet person of commodity-money relations distinctive for the market) [15].

Thus, based on the results of the analysis, the following general conclusions can be made on the cultural aspect of the creation, translation and perception of Western textbooks on economics in the Latvian and Russian spaces, which practically coincide with the conclusions of Weber [64]: (1) Western industrial civilization is unique; (2) capitalism, the development of which is determined mainly by social-cultural factors, is endogenous to the West and is the result of an exclusively Western path of development; (3) the modernization of the East is at 
least hampered. However, capitalism as a type of social actions for Weber is not equal to capitalism as a mode of production that forms the basis of the industrial society. Capitalism happened in almost all societies, on the basis of all religions, including Eastern, but it could only develop towards the typical capitalism in Western Europe and the USA. That is, "capitalist activity is possible in any society, however, according to Weber, in order to become the fundamental essence of society, it needs spiritual legitimation, while Marx spoke of economic necessity" [59].

Case study of the Russian translation and perception of the classical textbook on economics by Samuelson which first appeared in the USA in 1948, and in the Russian space in 1964 (when Latvia was a part of the USSR and Russian-speaking space), almost 30 years before the transition of Russia (and Latvia) to the market economy. This fact was a big surprise for us, since it raised the question on the necessity and possibility of translating into Russian of "the most widespread bourgeois textbook on political economy in the capitalist world", according to the Introduction of 12 pages of the devastating text which preceded the translation of the $5^{\text {th }}$ edition of this classical textbook in 1964 with the mark "for scientific libraries" (the library of the then Daugavpils State Pedagogical Institute, today the Daugavpils University). The Academician Arzumanyan explained the need to translate this 'bourgeois' textbook into Russian: "In this work, Samuelson appears not as the head of any school or scientific direction, but as a systematizer of the contemporary political and economic views of bourgeois ideologists. According to him, $90 \%$ of the economists of the 'Western world' agree with the provisions included in the textbook. This is the 'value' of the book... The translation of the book, in which the theoretical baggage of our ideological enemy is presented in sufficient detail, provides full-scale material for its criticism from the standpoint of creative Marxism-Leninism" [42]. Thus, the market terminology and market textbook on economics appeared in the special access space of the economic discourse in Latvia and Russia long before the beginning of their transition to the market - as 'a whipping boy' in the narrow academic community.

Samuelson assessed the fact of the first 1964 Russian translation of his textbook in his "Reflections on the $46^{\text {th }}$ birthday of the classic textbook on economics" (1997): "Even in the former Soviet Union, this Trojan horse was translated into Russian, thus contributing to the fall of the command economy, ineffectively managed by a totalitarian bureaucratic apparatus" [45]. Here the economic discourse is most closely intertwined with the political one, leaving open the question of how the 1964 Russian translation of Samuelson's textbook was perceived.

The next analyzed edition was a two-volume textbook on economics by Samuelson, which was published in Russia after the collapse of the USSR with absolutely no comment (there was no introductory article, no afterword) [43; 44]. In fact, it was the same 1964 translation published 'with minor reductions'. However, at least five last chapters, which we did not find in the 1964 textbook, were removed: on racial and gender differences; quality of life - poverty and inequality, ecology and growth, love and justice; full employment and the price of 
stability in the mixed economy; the wind of change; the evolution of economic doctrines; and alternative economic systems. Just a quote from these removed chapters explains the reason for such 'minor reductions' in 1964, even in the edition with the mark 'for scientific libraries': "It is obvious that the Soviet Union will not soon (and even then hardly) surpass our actual GNP. As for the level of well-being per capita, this is unlikely to happen at all" [44]. Such statements opposed the Soviet economic discourse presented in the Afterword by Professor Kudryavtsev for the first 1964 Russian translation of the fifth edition of the classic textbook: "The growth rates of production in the United States, as you know, are much lower than in the USSR and other socialist countries" [42], and in the Introduction about "the historical inevitability of the death of capitalism... American working people sooner or later, but inevitably will raise the banner of true freedom and brotherhood - the banner of socialism!" [42].

Thus, the first (since 1990) translation into Russian of Samuelson's textbook was the translation of its $15^{\text {th }}$ edition published in 1997 (co-authored with Nordhaus). This textbook, in contrast to the 1994 edition without comments by Russian economists, presented an enthusiastic "Foreword to the Russian edition" written by Russian economists [45]. In 2009, the last available Russian translation of Samuelson's classic textbook was published as the translation of its $18^{\text {th }}$ English edition.

The comparison of the comments of Soviet/Russian economists to the Russian editions of this classic textbook is presented in Table 2. These comments allow to follow the formation of the market economic discourse in the Russian space: (1) an absolutely negative perception (and at the same time translation into Russian) of the "bourgeois economic theory of capitalist countries"; (2) a tacit shock from the fact that this particular "bourgeois textbook" becomes one of the leading economic texts for educating economists in the Russian space of the 1990s; (3) market romanticism and idealization of this textbook; (4) the golden mean of applied attitudes to this textbook, devoid of both derogatory and enthusiastic emotions.

In the Russian translations of Samuelson's textbook in the 1990s (in fact, a 1964 translation), there are the following unusual terms for the contemporary Russian economic discourse: 'economic formation' (экономическая формация), 'business enterprises' (деловые предприятия), 'smallest enterprises' (мельчайшие предприятия), 'work relationships' (трудовые отношения), 'speculation economy' (экономика спекуляиии) [44], 'appointed market prices' (назначаемые рыночные ценьы) [51], 'means of production (land and capital)' (средства производства (земля и капитал)), 'productive forces of the market' (производительные силь рынка) [45]. Such terms are no longer found in the 2009 Russian translation of the textbook by Samuelson and Nordhaus, for these terms do not reflect the cultural background of the Soviet and post-Soviet translators, which influenced the translation of the market terminology as completely new to them in the 1990s (and even more so in the 1960s). Furthermore, the linguistic discourse analysis identified some emotional softening of the Russian economic discourse: from 'warring schools in macroeconomics' (враждующие школь в макроэкономике) [45] to 'competing 
macroeconomic schools' (соперничающие макроэкономические иколь) [46] in the Russian translations of Samuelson's textbook.

Table 2

\section{Comments of Soviet/Russian economists on the Russian editions of the textbook by Samuelson}

\begin{tabular}{|c|l|}
\hline Year & \multicolumn{1}{c|}{ Comments } \\
\hline 1964 & $\begin{array}{l}\text { Samuelson's textbook is a convincing and substantive confirmation of the position of } \\
\text { the Program of the CPSU that bourgeois teachings and schools did not stand up to } \\
\text { historical verification. They cannot give a scientific answer to the questions put forward } \\
\text { by life. The bourgeoisie is no longer in a position to put forward ideas that could } \\
\text { captivate the masses. More and more people in capitalist countries are denying the } \\
\text { bourgeois worldview. Bourgeois political ideology preached the dogma of the eternity } \\
\text { and inviolability of capitalism. How many papers have been written to prove that } \\
\text { capitalism is the only possible mode of production. How many poisoned arrows were } \\
\text { shot to Marxism which proclaimed that capitalism is a historically transient system and } \\
\text { socialism will inevitably replace it [42]. }\end{array}$ \\
\hline $1994 a$, & $\begin{array}{l}\text { No comments from Russian economists. } \\
1994 b\end{array} \quad \begin{array}{l}\text { This book is a synthesis of high science and high art of expressing thought. Therefore, } \\
\text { we publish the book without any cuts and abbreviations in order to give readers the } \\
\text { opportunity to fully appreciate not only clear logic and the highest scientific level, but } \\
\text { also the elegance of the authors' style. Each textbook is designed for certain readers, } \\
\text { and it would be logical to address the introductory textbook to those who are starting } \\
\text { their way in economics. However, we are convinced that not only those uninitiated in the } \\
\text { mysteries of economic science, but also wise readers will benefit and enjoy reading, for } \\
\text { the beauty of scientific thought will always attract true connoisseurs [45]. }\end{array}$ \\
\hline $\begin{array}{l}\text { The Economics of Samuelson and Nordhaus is a classic textbook on the economic } \\
\text { theory, which has not lost its relevance for fifty years. This book is used by thousands } \\
\text { of students in different countries to study economics. After reading this book, the } \\
\text { reader will understand the complex mechanism of the contemporary economy, learn } \\
\text { the basics of the economic theory and the latest trends in the development of the } \\
\text { economic thought. The book is intended for students and teachers of economic } \\
\text { faculties, and for any thoughtful reader interested in global trends of the world } \\
\text { economy and politics [46]. }\end{array}$ \\
\hline 2009
\end{tabular}

As Samuelson noted in the Foreword to his textbooks, thereby contributing to our linguistic discourse analysis: "In the social sciences one should especially beware of the 'tyranny of words'... Words can turn out to be treacherous also because we are not indifferent to them. Thus, a person who approves a government program to accelerate economic growth may call it 'reasonable planning', while a person who dislikes this program will describe it as 'totalitarian bureaucratic regulation'. Who can demur at the first and who can agree with the second? You do not need to be an expert in semantics - the science of the semantic meaning of language - to understand that scientific discussion requires avoiding, as much as possible, such emotional terminology" [43].

It is interesting that with the scientific heritage of Weber, the founder of the concept of cultural determinism in the social development, a metamorphosis similar to the classical textbook by Samuelson took place in the Soviet and post-Soviet cultural spaces. This is typical for all cases of science politicization [59]. From the oppositional thinker banned during the ideological domination of MarxismLeninism, in post-reform Russia Weber became an opposite - the ideologist for theorists of the Russian path of development. By criticizing the views of Weber, the Soviet social science pointed to its opposite - to Marxism, spoke of the 
incompatibility of two ideas (idealism and materialism) in the interpretation of the social. Today, there are attempts to literally merge the theory of Weber with the theory of Marx, leveling out methodological differences that are rather mutually exclusive than complementary, regardless of the social-economic and political situation: "It is impossible to merge two positions, to present one as an addition to the other... since Weber created his theory precisely as an alternative to Marxism. In his writings, he literally polemicizes with Marx, opposing his economic determinism with sociology of religion" [59].

The analysis of the social context of the creation, translation and perception of Latvian and Russian textbooks on economics of the 1990s, 2000s and 2010s revealed the conceptual problem of the economic science in the Latvian and especially Russian spaces: despite the demonstration of the existence of some general economic theory $[4 ; 5]$, even such universal economic processes as production and distribution are often explained in different systems of references depending on the beliefs of the textbook author(s). In particular, such a fairly contemporary textbook as Economic Geography and Regional Studies [28] is written in an absolutely Marxist language/terminology, which proves that "translation studies are able to discern social asymmetries behind linguistic ones" [38].

We agree with the statement of the American economists Heilbroner and Thurow, consistent with Weber's methodology of cultural determinism: "The real challenge of our time lies not in economic problems, but in the political and moral values that are always present in our economic behavior. Economics is the language we use when talking about the functioning and capabilities of our system, but it is not at all the language in which we discuss the value of the system itself or decide which elements should be preserved and which ones should be changed. Politics and morality - our collective will and our personal value systems - remain the foundation of society" [15].

Given the social-economic metamorphoses both over the past 30 years and in earlier periods, we emphasize the special importance of critical thinking in the creation, translation and perception of textbooks on economics, because there are no reasons to believe that the today's economic discourse of the Latvian and Russian spaces suddenly lost its ideological background which has existed for decades. The current social context with its ideologies is also shaping the economic discourse at which we, perhaps, in the future will look at with the same bewilderment as we look at the economic discourse of the 1960s today. We have to critically assess any textbook (especially with emotional terminology) without taking for gospel everything written on economics. The linguistic discourse analysis revealed a certain formality and superficiality of assimilation of the webs of significance that is unusual for the Latvian and Russian economic discourses. We believe that the study of the social context of creation, translation and perception of textbooks on economics can be useful and interesting for other countries, especially for the countries of Central and Eastern Europe, which, like Latvia and Russia, have experience of the socialist economy and of the transition to the market. 


\section{Notes}

(1) Thus, the structural-factor operationalization in the sociological research involves a 'separation' of the 'social text' (structure) from its context (external and internal factors).

(2) 'Market rails' is a widespread metaphor in the Russian economic discourse [13]. In the Latvian economic discourse, it did not become widespread, and the 'transition to the market economy' (pāreja uz tirgus ekonomiku) is usually used [49].

(3) For instance, books on the Russian labor market were published already in the early 1990s [32], although the national labor market did not exist.

\section{References}

1. Bakanov M., Sheremet A. (1999). Teorija ekonomicheskogo analiza [Theory of Economic Analysis]. Moscow; 1999. (In Russ.).

2. Basovsky L. Mirovaja ekonomika [World Economy]. Moscow; 2010. (In Russ.).

3. Balinson L. Professionalny diskurs kak predmet lingvisticheskogo izuchenija [Professional discourse as an object of the linguistic study]. Vestnik VGU. 2009; 9 (1). (In Russ.).

4. Bikse V. Ekonomikas teorijas pamatprincipi [Basic Principles of Economics]. Riga; 2007. (In Latv.).

5. Borisov E. Ekonomicheskaja teorija [Economic Theory]. Moscow; 2000. (In Russ.).

6. Brown G., Yule G. Discourse Analysis. Cambridge; 1983.

7. Danesi M., Greco S. (Eds.). Case Studies in Discourse Analysis. Licom Studies in Pragmatics. 2016. URL: https://www.researchgate.net/publication/301815499_Case_studies_in_Discourse_ Analysis_ed M_Danesi_S_Greco

8. Eatwell J., Milgate M., Newman P. (Eds.). "Nevidimaja ruka" rynka ["Invisible Hand" of the Market]. Moscow; 2009. (In Russ.).

9. Ellman M. Socialist Planning. Cambridge; 2014.

10. Garancha B. Vards - apakskomisijai. Ekonomikas terminologijas apakskomisija (ETAK). Terminologijas Jaunumi [The floor for the subcommittee. Subcommittee on Economic Terminology. Terminology News]. 2004. URL: https://termini.gov.lv/komisija/vardsapakskomisijai-ekonomikas-terminologijas-apakskomisija-etak. (In Latv.).

11. Geertz C. Interpretatsija kultur [Interpretation of Cultures]. Moscow; 2004. (In Russ.).

12. Gilbert G., Mulkay M. Opening Pandora's Box. A Sociological Analysis of Scientists' Discourse. Cambridge; 1984.

13. Gurijanov S., Nochevnik M. (Eds.). Rynochnaja ekonomika: vybor puti [Market Economy: Choosing a Path]. Moscow; 1991. (In Russ.).

14. Harrison M. The Soviet economy, 1917-1991: Its life and afterlife. Independent Review. 2017; 22 (2).

15. Heilbroner R., Thurow L. Ekonomika dlja vseh [Economics for Everyone]. Novosibirsk; 1994. (In Russ.).

16. Hernandez-Guerra C. An overview of the approaches and methods for analysing a text from a discursive viewpoint. ONOMAZEIN. 2014; 30.

17. Hofs K., Marinska K. Biznesa ekonomika [Business Economics]. Riga; 2002. (In Latv.)

18. Hofstede G., Hofstede G.J., Minkov M. Cultures and Organizations: Software of the Mind. New York; 2010.

19. Hofstede G. Dimensions of national culture. 2021a. URL: https:/hi.hofstede-insights.com/nationalculture

20. Hofstede G. Country comparison. 2021b. URL: https://www.hofstede-insights.com/countrycomparison/latvia,russia,the-usa

21. Hutabarat E., Herman A., Silalahi D., Sihombing P. An analysis of ideational metafunction on News Jakarta Post about some good Covid-19 related news. Voices of English Language Education Society. 2020; 4 (2).

22. Information portal of supporters of the referendum on the responsibility of the authorities to the people. Politicheskaja ekonomija. Stalinsky uchebnik 1954 [Political economy. Stalin's textbook of 1954]. 2021. URL: https://zaotvet.info/content/politicheskaja_jekonomija_ stalinskij_uchebnik_1954. (In Russ.). 
23. Junior Achievement Latvian Branch. Lietiska ekonomika. Studiju celvedis [Applied Economics. Study Guide]. Per. s angl. Lielvarde: Lielvards; 1995 (In Latv.).

24. Kanarejkin S. (Ed.). Ekonomiks: teorija i praktika [Economics: Theory and Practice]. Vol. 1. Saint Peterburg; 1993. (In Russ.).

25. Kibrik A. Analiz diskursa v kognitivnoj perspektive [Discourse Analysis in the Cognitive Perspective]. Diss. d.f.n. Moscow; 2003. (In Russ.).

26. Kondratieva T. Leksiko-semanticheskie i derivatsionno-metajazykovye osobennosti terminosfery 'Ekonomika-Rynok-Pravo' (na materiale russkogo, anglijskogo i nemetskogo jazykov) [LexicoSemantic and Derivational-Metalanguage Peculiarities of the Terminological Sphere 'Economics-Market-Law' (Based on the Materials of Russian, English and German)]. Avtoreferat diss. k.f.n. Krasnodar; 2001. (In Russ.).

27. Krugman P., Obstfeld M. Mezhdunarodnaja ekonomika: teorija i politika [International Economics: Theory and Policy]. Moscow; 1997. (In Russ.).

28. Kuzbozhev E., Kozieva I., Svetovtseva M. Ekonomicheskaja geografija i regionalistika [Economic Geography and Regional Studies]. Moscow; 2010. (In Russ.).

29. Litan R., Herring R. (Eds.). Brookings-Wharton Papers on Financial Services. Washington; 2001.

30. McConnell C., Brue S. Ekonomiks: printsipy, problemy i politika [Economics: Principles, Issues and Policies]. Moscow; 2008. (In Russ.).

31. Menshikovs V. Latgale cela uz konkuretspejigu tirgu [Latgale on the Way to a Competitive Market]. Daugavpils; 1997. (In Latv.).

32. Nikiforova A. Rynok truda: zanjatost $i$ bezrabotitsa [Labor Market: Employment and Unemployment]. Moscow; 1991. (In Russ.).

33. Ostrovitjanov K., Shepilov D., Leontiev L., et al. Politicheskaja ekonomija [Political Economy]. Moscow; 1954. (In Russ.).

34. Petrakov N. (Ed.). Ne smet komandovat! [Do Not Dare to Command!]. Moscow; 1990. (In Russ.).

35. Piketty Th. Kapital v XXI veke [Capital in the Twenty-First Century]. Moscow; 2015. (In Russ.).

36. Plotkans A. Cita ekonomika [Other Economy]. Riga; 2010. (In Latv.).

37. Pokornjak V. "Vo mne ubili rynochny romantizm" [My market romanticism was destroyed]. 2002. URL: https://ksonline.ru/nomer/ks/-/id/12392. (In Russ.).

38. Prunch E. Puti razvitija zapadnogo perevodovedenija: ot jazykovoj asimmetrii k politicheskoj [Ways of the Western Translation Studies Development: From Linguistic Asymmetry to the Political]. Moscow; 2015. (In Russ.).

39. Putele I. (Comp.). Aktualas tendences terminologijas teorija un prakse [Current Trends in Terminology Theory and Practice]. Riga; 2013. (In Latv.).

40. Rajzberg B. Eksperimentalnye uchebnye programmy izuchenija ekonomiki v nachalnyh, srednih $i$ starshih klassah obscheobrazovatelnyh shkol, gimnazij, litseev [Experimental Curricula for Studying Economics in Primary, Secondary and Senior Grades of Comprehensive Schools, Gymnasiums, Lyceums]. Moscow; 1994. (In Russ.).

41. Rumjancevs A., Kozlovs G., Volkovs M., Mileikovskis A., Atlasa M., Azarova M., Belousovs R., Mancevs V., Mokhovs N., Mrachkovska I., Skipetrovs A. Politekonomija [Political Economy]. Riga; 1985 (In Latv.).

42. Samuelson P. Ekonomika [Economics]. Moscow; 1964. (In Russ.).

43. Samuelson P. Ekonomika [Economics]. Vol. 1. Moscow; 1994. (In Russ.).

44. Samuelson P. Ekonomika [Economics]. Vol. 2. Moscow; 1994. (In Russ.).

45. Samuelson P., Nordhaus W. Ekonomika [Economics]. Moscow; 1997. (In Russ.).

46. Samuelson P., Nordhaus W. Ekonomika [Economics]. Moscow; 2009. (In Russ.).

47. Sarna A. Diskurs-analiz [Discourse Analysis]. URL: https://gtmarket.ru/concepts/7232 (In Russ.).

48. Silaški N. Terminological synonymy - an oxymoron that has become the rule. Vučo J., Mirić M., Ignjačević A. (Eds.). Language for Specific Purposes - Theory and Practice. Belgrade; 2009.

49. Sinicins M. Ekonomika vidusskolai [Economics for Secondary School]. Riga; 2009. (In Latv.).

50. Spiridonova E. Semanticheskie osobennosti ekonomicheskih terminov (na materiale russkogo $i$ anglijskogo jazykov). [Semantic features of economic terms (on the example of Russian and English languages). Aktualnye problemy teoreticheskoj i prikladnoj lingvistiki. Ulyanovsk; 2010. (In Russ.). 
51. Strazdina V., Viksnins M. (Comp.). Tirdzniecibas ekonomikas, organizacijas un parvaldes terminu vardnica [Terminological Dictionary of Trade Economics, Organization and Administration]. Riga; 1992. (In Latv. and Russ.).

52. Streletskaya I., Novakovskaya E. Nekotorye osobennosti perevoda ekonomicheskih tekstov s anglijskogo jazyka na russkij [Some features of the translation of economic texts from English to Russian]. Mir Sovremennoj Nauki. 2011; 6. (In Russ.).

53. Tay D. Time Series Analysis of Discourse Method and Case Studies. Routledge; 2019.

54. Tracy M. Lauksaimnieciba un partika tirgus ekonomika: Ievads teorija, prakse un politika. [Agriculture and Food in the Market Economy: Introduction to Theory, Practice and Policy]. Per. s angl. Riga; 1996. (In Latv.).

55. Trotsuk I.V. Diskursivnoe konstruirovanie sotsialnoy realnosti: kontseptualnye osnovaniya i empiricheskie priyemy razoblacheniya "skvernykh" praktik [Discursive construction of social reality: Conceptual foundations and empirical devices for unmasking the "abominable" practices. Russian Sociological Review. 2014; 13 (2). (In Russ.).

56. Trotsuk I.V. Diskursivnye reprezentatsii (kapitalisticheskih) itogov "kitayskogo ekonomicheskogo chuda" [Discursive representations of the (capitalist) results of the "Chinese economic miracle"]. Russian Sociological Review. 2020; 19 (2). (In Russ.).

57. Trotsuk I.V. Textual analysis within sociological research: Terminological rather than methodological difficulties? RUDN Journal of Sociology. 2011; 2.

58. Trotsuk I. When methodology beats techniques; or, Why we prefer discourse and narrative analysis to interpret textual data. Russian Sociological Review. 2015; 14 (3).

59. Trubitsyn D. Kulturny determinizm v kontseptsii modernizatsii: filosofsko-metodologichesky analiz [Cultural determinism in the concept of modernization: A philosophicalmethodological analysis]. Voprosy Filosofii. 2009; 8. (In Russ.).

60. Ukhvanova-Shmygova I. Kauzalno-genetichesky podkhod v kontekste lingvistiki diskursa [The Causal-Genetic Approach in the Linguistics of Discourse]. Minsk; 2014. (In Russ.).

61. Van Dijk T. Ideology and discourse analysis. Journal of Political Ideologies. 2006; 11 (2).

62. Van Dijk T. Discourse and Context. A Sociocognitive Approach. Cambridge; 2008.

63. Vid T., Ivanov E. Novaja filosofija planirovanija [New Planning Philosophy]. Moscow; 1990. (In Russ.).

64. Weber M. Izbrannye proizvedenija [Selected Works]. Moscow; 1990. (In Russ.).

DOI: 10.22363/2313-2272-2022-22-1-168-185

\section{Экономические тексты как отражение социальной реальности переходного периода в Латвии и России*}

\section{И. Миетуле ${ }^{1}$, В. Комарова ${ }^{2}$, И. Островска ${ }^{2}$, С. Игнатьев ${ }^{3}$, Б. Хейманис ${ }^{3}$}

${ }^{1}$ Резекненская академия технологий Атбривошанас ал., 115, LV-4601, Резекне, Латвия

${ }^{2}$ Даугавпилсский университет

ул. Виенибас 13, LV-5401, Даугавпилс, Латвия

${ }^{3}$ Балтийская международная академия)

ул. Ломоносова 4, LV-1019, Рига, Латвия

(e-mails: iveta.mietule@rta.lv; vera.komarova@du.lv; inta.ostrovska@du.lv; igs@bk.ru; boriss.heimanis@gmail.com)

Аннотация. Целью исследования является сравнительный анализ репрезентаций перехода Латвии и России к рыночной экономике в экономических текстах. Объект исследования - учебники экономики $(\mathrm{N}=61)$ на латышском и русском языках, книги «трех поколений»

* (C) Миетуле И., Комарова В., Островска И., Игнатьев С., Хейманис Б., 2022

Статья поступила 09.10.2021 г. Статья принята к публикации 17.12.2021 г. 
(1990-х, 2000-х и 2010-х годов), имеющиеся в библиотеке Даугавпилсского университета. Первое из рассматриваемых изданий вышло в свет в 1993 году, несколько последних в 2015 году. В качестве отправной точки анализа взят переводной учебник Самуэльсона 1964 года, выходящий за временные рамки исследования, но необходимый для более глубокого анализа учебников экономики. Исследование проведено с помощью методов описательного анализа и кейс-стади в рамках лингвистического дискурсивного анализа, опирающегося на методологию культурного детерминизма Вебера. Результаты исследования показали, что в 1990-е годы экономический дискурс США начал активно заимствоваться в Латвии и России, но деловая культура Соединенных Штатов существенно отличается от латвийской и российской. Лингвистический дискурсивный анализ позволил выявить концептуальную проблему современной экономической науки в Латвии и России: несмотря на якобы существование некоей общей экономической теории, в действительности даже базовые экономические процессы часто объясняются в разных системах координат - в зависимости от убеждений автораов экономических текстов. Принимая во внимание опыт социально-экономических трансформаций последних тридцати лет и более ранних периодов, авторы подчеркивают особую важность критического мышления при создании, переводе и оценке современных экономических текстов. Это особенно важно, поскольку нет оснований полагать, что в 1990-е годы культурная составляющая экономического дискурса Латвии и России существенно изменилась в направлении рыночной ориентации. Перед современными читателями экономических текстов стоит непростая задача критической оценки прочитанного - особенно в тех случаях, когда авторы текстов активно используют эмоциональную терминологию.

Ключевые слова: текст; социокультурный контекст; экономический дискурс; экономические тексты; лингвистический дискурсивный анализ; культурный детерминизм 